\title{
Introduction
}

\section{Introduction to Symposium on Left Authoritarianism: Comparative Politics and Comparative Political Theory}

\author{
Takamichi Sakurai | ORCID: 0000-0002-8282-1691 \\ Keio University, Tokyo, Japan \\ Goethe University Frankfurt, Frankfurt, Germany \\ tsakurai@sfc.keio.ac.jp, sakurai@em.uni-frankfurt.de
}

The symposium presented in this second issue of Comparative Political Theory aims to foster dialogue between comparative politics and comparative political theory (СРT). This introduction clarifies how political science and political theory intersect in comparative enterprises. While СРT is becoming a global interest, particularly in normative and inclusive terms, it does not seem to draw enough attention to interpretive and descriptive ventures. However, it is possible to discern a great opportunity to develop the intersection in current issues of authoritarianism, in which both the empirical and theoretical disciplines are vigorously involved. In particular, right and left populism characteristically pertaining to those issues link the disciplines profoundly. Cas Mudde, Carlos de la Torre, Cristóbal Rovira Kaltwasser, Jan-Werner Müller, Paulina Ochoa Espejo, and Yannis Stavrakakis are archetypal scholars who work on such topics.

Authoritarianism was approached by myriad scholars from intricate perspectives in the entire twentieth century (e.g., Adorno et al., 1950; Altemeyer, 1996; Collier, 1979; Fromm, 1941; Germani, 1978; Institut für Sozialforschung, 1936; Jalal, 1995; Smith, 1989). In the twenty-first century, political scientists of a more empirical bent have continued to research the topic of authoritarianism as an ideological concept and as a political phenomenon (Albertus and Menaldo, 2018; Bunce et al., 2010; Diamond et al., 2016; Frantz, 2018; Levitsky 
and Way, 2010; Levitsky and Ziblatt, 2018; Mounk, 2018; Runciman, 2018). Recently the topic has also attracted the attention of scholars in political theory. American critical theorists, notably Wendy Brown et al. (2018), devote themselves to detecting the nature of the twenty-first-century authoritarian personality shaped in a neoliberal fashion. By focusing on actual political movements burgeoned recently, William Connolly (2017) has become involved in discussion of an authoritarian far-right issue, fascism, thereby offering a clear description of problems with Trumpist politics. In relation to these works, Chantal Mouffe (2005, 2018) in conjunction with Ernesto Laclau (2001) has portrayed the foundations of a discourse on far-left politics in political theory, thereby developing normative and prescriptive issues of the political in an interpretive manner. What is discernible in recent works of these eminent political theorists is their considerable attention to political affairs per se rather than to normative theory. Surprisingly, the tradition of an exclusive focus on the res publica in political theory has indeed lasted since Machiavelli, but perhaps more rigorously since Max Weber - this implies the intersection of social theory and political theory, which best elucidates empirical cooperation between those fields. Moreover, it also relates to realism in political theory (Galston, 2010; Philp, 2012). This introductory essay particularly stresses cooperation between empirical and theoretical disciplinary frameworks.

Authoritarianism is a traditional occurrence in politics; by becoming more involved in the study of this phenomenon, political theory can showcase its raison d'être. For this purpose, it is worthwhile for political theory to approach political science in comparative terms and thereby to become more actively engaged in looking into actual political issues, not least into socio-culturally diverse issues, more in an interpretive manner than in a normative manner. This is precisely how CPT is expected to play its role in terms of politics - with respect to the disciplinary role of $\mathrm{CPT}$, I herein shine a light on structures of politics rather than on those of political thinking, which are inextricably intertwined with politics per se, particularly in relation to political ideologies.

In the symposium, $C P T$ is pleased to offer several fascinating discussions of "left authoritarianism" proposed by prominent theorists of democracy and populism and a promising social theorist who are all working more in empirical fields. Their focus is therefore more on authoritarian phenomena than on the ideologies on which they are based. But this does not insinuate that they are less intriguing to us political theorists; rather, we find a good opportunity to enrich CPT, and therefore political theory, through examining a political phenomenon in Latin America, East Asia, and Europe in terms of leftist ideologies. We may thereby be able to seek effective ways of illuminating our understanding of socio-culturally divergent phenomena by means of diverse political theories, 
a legitimate approach that is much more contiguous to empirical political science than to normative political theory and that will hopefully be added to CPT.

Laurence Whitehead, a distinguished theorist of democracy, opens the discussion of left authoritarianism, focusing on the "authoritarian temptation." He argues that while surprisingly only political regimes such as the North Korean and the Khmer Rouge are categorized as the full-fledged "radical left," this category is of course not limited to them but broadly construed: various "national liberation" campaigns, Jacobins, anarchists, Bolsheviks, and "twenty-first century socialism[s]." Whitehead maintains that an evaluation of the authoritarian disposition of the radical left, a manifestation of left authoritarianism, is built upon a tension between "internal features" intrinsic to revolutionary endeavors and "external reactions" that are necessarily attributed to the survival of regimes. Syriza and Podemos are, he remarks provocatively, "two borderline examples." Regardless of these examples, Whitehead implies that the radical left can verge on authoritarianism when it induces authoritarian propensities in its own internal mechanisms.

Óscar García Agustín, a reputed theorist of left populism, compares European and Latin American variants of left populism in terms of their confrontations with authoritarianism. He admits that left populism has not sufficiently faced up to neoliberalism per se, but he makes a positive assessment of it on the grounds of its potential to defeat neoliberal authoritarianism. According to Agustín, neoliberalism, which sometimes serves to organize right-wing populism, is rather a clear manifestation of authoritarianism, and left-wing populism does not exhibit authoritarian propensities. From this perspective, he seeks to defend left populism on the grounds that it aims to stand up for and augment democracy against neoliberal authoritarianism and far-right populism. As he phrases it, "it is not by chance ... that left populism presents itself as an alternative against a different type of authoritarianism." The cross-lingual bibliography including Spanish references to Latin American politics he provides demonstrates a rich diversity of his paper.

Carlos de la Torre, one of the most prominent theorists of populism, discusses populism from a broader perspective, while introducing predominant views in its discourse: "populism is democratizing"; "populism leads to autocracy; "populism is a sui-generis combination of autocracy and inclusion." He rejects the validity of the concept of "competitive authoritarianism" and instead promotes the concepts of "populist regimes" and "polarized democracies" in the sense that they illuminate the coexistence of inclusion and autocracy in the control of a regime that changes elections to the sole legitimate tool for politics by means of the friend/enemy dichotomy and that makes the people "unitary actors" and the leader the "savior of the people." De la Torre 
does not hesitate to see left populism in Latin America under the category of authoritarianism, but he is also not reluctant to apply the notion of authoritarianism to left populism in general.

Alzo David-West, a proficient social theorist, sets about analyzing North Korea by way of the concept of authoritarianism. Significantly, he applies Hobbes's concepts of the "artificial man" and the "perpetual war," thereby seeking to detect difficulties with the North Korean polity. On the basis of the view that "[a]lthough the country in the northern half of the Korean Peninsula is a decidedly modern polity, its combination of state absolutism and conservative proletarianism are unprecedented in the Western European and North American political traditions," David-West concludes that the "political system is a modern one in an authoritarian democratic genealogy." CPT as well as political theory more generally should be keen to learn how to engage in the Far Eastern political issue from his cross-culturally rich list of references.

One of the important issues concerning left authoritarianism is associated with the points of intersection and difference between populism and authoritarianism. The intersected points are discernible in Whitehead's, Agustín's, and de la Torre's discussions. These authors all link authoritarianism to characteristic propensities pertaining to temptations, traits, and features, rather than to a form of government with one-dimensional political structures. They see populism in some respects in the same line as authoritarian politics, particularly in the sense that those are both involved in increasing "polarization." De la Torre says that "left-wing populism exhibited a sui generis process of authoritarian inclusion to the political community" perse. On the other hand, Agustín stresses clear points of difference between them. He argues that populism in leftist forms entails democracy when it is built upon the solid foundations of civil society, and therein discerns an opportunity to develop a democratic politics. The essence of his discussion is whether authoritarianism is entirely separable from democracy in terms of propensities.

One of the other important issues is a link between authoritarianism and the communist radical left. This is well depicted by David-West in terms of North Korean politics. In particular, "authoritarian temptation" in Whitehead's sense is discernible most characteristically in the North Korean regime, which outlines an authoritarian disposition that manifests left authoritarianism as can be seen in David-West's discussion.

Significantly, Whitehead elaborates quite eloquently on the nature of political affairs in terms of the radical left.

When radical left ideas and aspirations are taken seriously it becomes possible to analyze this type of regime more dispassionately, and to pro- 
mote dialogue with their rulers from outside their own frame of assumptions. This can provide a balanced understanding of the authoritarian risks they face (risks also present in other regime types) and thus to explore possible common ground with them over such underlying values as human emancipation, inclusive governance, and the promotion of equality. In principle, after all, such aspirations are not restricted to the radical left, but on the contrary have near-universal appeal.

What can we derive from Whitehead's perspective of the political nature of the radical left? It is, undoubtedly, that it is necessary to investigate political movements per se in order to touch upon and discuss their essence pertaining to political norms and therefore to shine a light on substantive political phenomena expressing ideological symptoms. Whitehead's description astutely reminds us that all in all what we political theorists fail to do is to dive into politics per se. Surprisingly, this lamentable tradition of contemporary political theory neglecting "substantive political concerns" has been still deep-seated even since Jeffrey Isaac's 1995 warning against the tradition (Isaac, 1995, p. 646). Interpretatively oriented assemblages of comparative politics and CPT can even serve to deal with this long-lasting difficulty.

\section{References}

Adorno, T.W., Frenkel-Brunswik, E., Levinson, D.J., \& Sanford, R.N. (1950). The Authoritarian Personality. New York: Harper \& Row.

Albertus, M. \& Menaldo, V. (2018). Authoritarianism and the Elite Origins of Democracy. Cambridge: Cambridge University Press.

Altemeyer, R.A. (1996). The Authoritarian Specter. Cambridge, MA: Harvard University Press.

Brown, W., Gordon, P.E., \& Pensky, M. (2018). Authoritarianism: Three Inquiries in Critical Theory. Chicago: Chicago University Press.

Bunce, V., McFaul, M., \& Stoner-Weiss, K. (2010). Democracy and Authoritarianism in the Postcommunist World. New York: Cambridge University Press.

Collier, D., ed. (1979). The New Authoritarianism in Latin America. Princeton, NJ: Princeton University Press.

Connolly, W.E. (2017). Aspirational Fascism: The Struggle for Multifaceted Democracy under Trumpism. Minneapolis: University of Minnesota Press.

Diamond, L., Plattner, M.F., \& Walker, C., eds. (2016). Authoritarianism Goes Global: The Challenge to Democracy. Baltimore, MD: Johns Hopkins University Press. 
Frantz, E. (2018). Authoritarianism: What Everyone Needs to Know. New York: Oxford University Press.

Fromm, E. (1941). Escape from Freedom. New York: Rinehart \& Company.

Galston, W. (2010). Realism in Political Theory. European Journal of Political Theory 9 (4), pp. 385-411.

Germani, G. (1978). Authoritarianism, Fascism, and National Populism. New Brunswick, New Jersey: Transaction Books.

Institut für Sozialforschung, ed. (1936). Studien über Autorität und Familie. Paris: Alcan. Isaac, J.C. (1995). The Strange Silence of Political Theory. Political Theory 23 (4), pp. $636-52$.

Jalal, A. (1995). Democracy and Authoritarianism in South Asia: A Comparative and Historical Perspective. Cambridge: Cambridge University Press.

Levitsky, S. \& Way, L.A. (2010). Competitive Authoritarianism Hybrid Regimes After the Cold War. New York: Cambridge University Press.

Levitsky, S. \& Ziblatt, D. (2018). How Democracies Die. New York: Crown.

Mouffe, C. (2005). On the Political. Abingdon, Oxon: Routledge.

Mouffe, C. (2018). For a Left Populism. London: Verso.

Mouffe, C. \& Laclau, E. (2001). Hegemony and Socialist Strategy: Towards a Radical Democratic Politics. London: Verso.

Mounk, Y. (2018). The People vs. Democracy: Why Our Freedom Is in Danger and How to Save It. Cambridge, MA: Harvard University Press.

Philp, M. (2012). Realism without Illusions. Political Theory 40 (5), pp. 629-49.

Runciman, D. (2018). How Democracy Ends. London: Profile Books.

Smith, W.C. (1989). Authoritarianism and the Crisis of the Argentine Political Economy. Stanford, CA: Stanford University Press. 